\title{
The Challenges of Value Re-Orientation in Nigeria's Tertiary Education System
}

\author{
Solomon J. Anzene \\ Directorate of Advancement and Linkages, Nasarawa State Polytechnic, Lafia, Nigeria. \\ Email: anzenejoe@yahoo.ca
}

\section{Doi:10.5901/mjss.2014.v5n14p221}

\begin{abstract}
The decay in the society has affected the values and moral character fabric of our tertiary education system. This has manifested in many social vices, which include Cultism, Drug abuse, Examination malpractice, Indecent dressing, Sexual harassment among others. This paper discussed the changes that have affected our ethical and moral values over the years in our tertiary education system and proffered suggestions on the way forward.
\end{abstract}

Keywords: Challenges, Values, Tertiary, Nigeria, Education

\section{Introduction}

Enu and Esu(2011), noted that values are basic beliefs and attitude in a society whether of individuals or groups which are considered worthwhile and serve as a guide to choices and behaviours in our daily life. Esu (2009), further defined values as ideals that guide or qualify your personal conduct, interaction with others and involvement in your career. Values help to inform one on how he or she can conduct one's life in a meaningful way. Different schools of thought therefore consider values to mean trait, practices, acts, ideals, beliefs, attitude and principles that a group or society acknowledge to be of merit, worthwhile, dear, acceptable and right. Values therefore are deep seated beliefs that influence people's actions and behaviours. It is therefore essential that every individual, group and indeed the entire nation must have core values which serve as the driving engines for growth and development (NOA, 2009).

Bolarin (2005), identified some dominant values which formed the core values upheld by a larger section of the Nigerian society to include the following; detesting laziness, dignity of labour, respect for parent/elders, hospitality, public spiritedness, respect for authority, hardwork, respect for sanctity of life, honesty and truthfulness. When these values are grossly compromised, then what you get is greed, corruption, dishonesty, violent crimes, political killings, kidnapping and so many other antisocial behaviours.

According to the National policy on Education(NPE, 2004), Tertiary Educational Institutions cover four major sections of Education as follows:

a) University Education Sector

b) Technical Education Sector

c) Teacher Education Sector

d) "Professional" schools

Specifically, University Education consists of the conventional Universities; Universities of Technology, Universities of Agriculture, Military University as well as private Universities. Technical Education consists of Polytechnics, Colleges of Technology and Technical/ Vocational colleges. Teacher Education on the other hand consist of conventional colleges of Education (Special \& Technical). The Professional schools consist of Monotechnic institutions.

\subsection{Causes Of Antisocial Behaviours In Our Campuses}

The causes of decay of moral values in our tertiary institutions of learning can be attributed to several factors, notable among them are:

(1) Lack of Parental care

(2) School Environment

(3) The role of lecturers

(4) Societal Influence 
(5) Government influence

\subsubsection{Lack of Parental Care}

Charity, they say begins at home. Therefore a good home training is sine-qua-non for overall child's development. This is because the home has been perceived as the first teacher to any child. Although as the child grows, other people around get involved in the training of the child. Consequently, it is assumed that proper supervision becomes very necessary at the tender age of any child(Kayode and Adeyinka, 2009).

In the past, children were trained to be well disciplined simply because parents were concerned about the behaviour of their children and they regarded such training as their primary responsibility. But today's parent have abandoned their primary responsibilities to raising their children in the way they themselves have been raised. Instead, they run after material wealth and fame leaving the responsibility of child discipline entirely in the hands of the school. This is more apparent in the tertiary education system where students are regarded as adults who need little or no supervision.

Another way in which the home contributes to student's indiscipline is the unlimited or unguided liberty or freedom granted by the parents to their children. Most children are over-protected and over pampered at home and thus become problematic in the school and society.

Most parents place high premium on wealth to be the pride of their children. They provide their children with all kinds of material needs to the extent that such children consider themselves better than other people around them including their teachers. Most times, you find such students riding in exotic cars and wearing very expensive dresses. They drive recklessly all over the place, causing avoidable accidents. They throw parties every now and then and one will hardly find them attending classes.

\subsubsection{School Environment}

Tertiary institutions in Nigeria today are confronted with massive increase in students enrolment with no corresponding increase in both human and material resources. Thus, most institutions are now faced with the problems of coping with the massive welfare responsibilities expected by the students. For instance, there are inadequate recreational and welfare facilities, inadequate library and laboratory facilities, shortage of classrooms for learning, inadequate exposure of students to reading materials. Ezeanya (1979), remarked that:

To expect that there will be high moral standards in all those ill-equipped institutions, where accommodation is poor, where there are no tables, poor lighting facilities and water supply will be to expect a miracle to happen.

These institutions have found themselves in such a situation because the financial allocation from government is grossly inadequate to meet their needs. Thus, they over enroll in order to generate more funds because of the need to supplement salaries and meet its running cost.

\subsubsection{The Role of Lecturers}

The attitude of lecturers in our tertiary institutions can either stamp out or promote social vices among students. Such attitudes include exploitation of students by lecturers, by compulsory sale of handouts, textbooks as well as sexual harassment in addition to receiving gratification of all kinds from the students can promote social vices. Moreover inadequate commitment to duty by lecturers as well as inadequate incentives and staff welfare policies are also factors that promote indiscipline in our tertiary institutions.

\subsubsection{Societal Influence}

The society in which the students develop and operate also have tremendous influence on their behaviours. Such things as inadequate transportations, water, accommodation and electricity in host communities as well as massive poverty in the land can promote social vices in the tertiary institutions.

Indeed the past two decades have witnessed unmitigated confusion and economic depression or unrestrained corruption and human misery, insecurity and nightmares or apathy, of wanton destruction of public utilities, kidnappings and assassinations. 
Sadly the present circumstances in our Tertiary Institutions present a bleak future for the students/graduates; massive unemployment, distorted academic calendars, as a result of frequent disruption of academic activities by staff and students alike. Hence programmes/courses that are designed to last for four sessions, i.e. 8 semesters for example, now take about 6-7 sessions or 12 semesters. Most worrisome is the incessant strikes, where the baton is passed from one union to the other. In fact when lecturers or non-academic staff are not on strike, the students are on their own rampage.

\title{
1.1.5 Government Influence
}

Government promotes immoral acts in tertiary institutions by involving students in politics and encouraging them to be partisan, apart from undue interference in union matters at the state and even NANS elections, sponsoring division among students, as well as encouraging them to undermine the school authorities. Some Governing Councils in most cases also do not help matters because instead of supporting efforts by authorities at controlling these students and curbing their excesses, they wittingly or unwittingly encourage these students to disregard constituted authorities. Most of the laws governing these institutions vest the power to discipline students on the Chief Executive or Head of such an institution. The Governing Council only has oversight functions and in most cases, is expected to be concerned with giving policy directions. But what happens in most cases is that they get directly involved in the day to day management of the affairs of these institutions with the resultant effect of breeding indiscipline since most times these students by-pass constituted authority and go directly to Council member(s) or even government. As a result, decisions taken by authorities are often upturned by these higher authorities. In quite a number of cases when investigations are being conducted on offences committed by a group of students, undue pressures from higher quarters are mounted to ensure that such students are not punished or have such punishment mitigated. The resultant affect of all these undue interference is gross indiscipline among both staff and students of our tertiary institution.

Summing up the level of indiscipline in our tertiary institutions, Nwabueze (1995) has this to say.

\begin{abstract}
"At the tertiary level, our Universities, Polytechnics, Colleges of Education have become perhaps the most fertile ground for social unrest and indiscipline. The factors responsible for this state of affairs are partly external and partly internal to the tertiary institutions. Among the external causes are insufficient funds, lack of coherent higher education policy by successive governments, undue interference with the school autonomy, corruption, unbridled quest for intellectualism and the enthronement of mediocrity in our society in place of excellence, the inversion of moral values."
\end{abstract}

One of course is not absolving Management of these institutions totally from blame. There is no doubt that some display gross incompetence and insensitivity in handling crisis situation in their tertiary institutions. If a head is incompetent or does no know how to manage crisis, the outcome is breakdown of law and order and indiscipline in such institution.

\section{EFfects of Antisocial Behaviours}

Educational Institutions that were supposed to be the custodians of the cherished values have been invaded and are contaminated by vices some of them are hereby briefly examined.

\subsubsection{Cultism}

According to Denga (1991), cultism is a system of religious belief and practice or an ideology. Orukpe (1988), defined secret cults as a group who share and propagate peculiar secret beliefs divulged to members. In addition their initiation procedures often involve secret rituals like swearing by some deity, human blood and other procedures, which send shivers down the spines of most people.

The origin of the phenomenon of cultism in Nigeria tertiary institution is traceable to the formation of pirate confraternity at the University of Ibadan in 1952 by Wole Soyinka and members of his group mainly as lobby group of students in order to score even with the University authorities. Besides, one of the objectives of the group was to inspire patriotic sentiments and to check the neo-colonialist mentality spreading among the nation's educated class due to western education. At that time, violence was not said to have manifested in their conduct. Nevertheless this initially peaceful group later snowballed into esoteric gangs whose members were highly steeped in ritualism and voodooism. From there, the phenomenon of cultism became pronounced in almost all the tertiary institutions in the country and the 
secondary schools. Secret cult groups are now dreaded on the campuses. Because of their secret activities and ascribed mysticism and power, members enjoy an aura of fearsomeness especially from non-members. Some of the most noble of these secret cult groups include the Sea dog, Black Axe, Aiye, Vicking, Amazons, White Angels, Black Brassieres, Buccaneers, Confraternity, etc.

Cultism leads to outbreak of violence on campuses and its attendant destruction of lives and property. The frequent outbreaks of cult in some campuses have generated feeling of fear and social insecurity among students and lecturers. The unhealthy rivalry among secret cult groups often intensify acts of terrorism and hatred among students on campuses. These sometimes result in the closure of tertiary institutions for quite a long time, which has negative effect on implementation of academic programmes.

Proper moral upbringing of children and wards by parent and guardians is recommended as a remedy to cultism in tertiary institutions in Nigeria. The youth should be properly counseled on peer group relationship. An innocent child can easily be transformed into a dangerous fearful young man if he is allowed to make friends indiscriminately.

\subsubsection{Examination Malpractice}

In recent times, examination malpractice has gone from simple 'giraffing' where students occasionally stretch their necks to catch glimpse of what they want to copy from other students' scripts to a variety of sophisticated methods which include; (a) Use of micro-chips'; writing very tiny summaries on pieces of paper, parts of the body, or on materials found within the venue. (b) Sorting'; in which students negotiate with corrupt lecturers for scores by rewarding' the lecturers in cash or kind (c) ECOMOG/ECOWA/OAU; which is an alliance among classmates, to communicate via coded 'language' (d) Hand-held smart devices such as modern cell phones(Anzene 2013).

One of the major causes of examination malpractice can be attributed to moral decadence in Nigeria because of our deplorable value system. In this country, cheating, dishonesty including embezzlement and stealing of public funds and properties do not attract the condemnation and punishment they deserve.

The emphasis on paper qualifications or certificates is another cause of examination malpractice. If admissions to schools and employment of graduates are based on actual performance of candidates during interviews or entrance examinations rather than on mere certificates, examination malpractice shall be discouraged or minimized.

Another major cause of examination malpractice is inadequate teaching and learning facilities such as classrooms, libraries, laboratories and even teachers compared to the population of students. Thus effective conduct of examination becomes difficult. Other students' vices such as cultism, drug abuse, sexual promiscuity and truancy are also encouraging examination malpractice on our campuses as students devote more time to them than their studies.

Since examination malpractice sows seed of fraud and criminal values in our society, this vice cannot allow us to realize our future greatness because it renders useless our certificate and debases the foundation for assessing our skills and capacity. Examination malpractice, therefore not only promotes breakdown of moral and ethical standards in our society but it also prevents achievement of meaningful and sustainable development for example in our aspiration to become one of the top twenty economies in the world by the year 20:2020.

\subsubsection{Drug Abuse}

A drug according to Olatunde (1979), is a substance of biological or chemical origin which when applied to a living tissue, produces an effect. Drugs include what are commonly called medicine and are not only substances which alter mood, perception or normal awareness as some people erroneously believe(Igbokwe, 1977).

Generally, there are certain drugs, which users including adolescents, become easily addicted to and therefore abuse a lot. These are mostly (i) Central Nervous system stimulants (ii) Central Nervous system depressants (ii) Hallucinogens (iv) Narcotic analgesics (v) Alcohol and (vi) Tobacco While Central Nervous System stimulants such as Amphetamine and Caffeine speed up people's reactions and counteract fatigues, the depressants calm people and relieve anxieties. Example of depressants include Phenobarbitone and Valium. Alcohol, though a social drug when taken in excess causes undesirable effects on individual personal judgment and social relationships.

Tobacco is a stimulant that increase mental alertness and in high doses causes unsteadiness and muscle tremors, Narcotic analgesics such a Morphine, Heroine and Opium are pain relievers with marked effect on mood of people.

The causes of drug abuse among students include; coping with pressures/stress of school life, ignorance, pleasure, curiosity, incorrect drug dosage, low self esteem, inferiority complex or feeling of inadequacy, and membership of group/peer pressure. Various reports about the factors associated with drug abuse suggest that parents have a primary role to play in reducing its incidence. Parents should ensure adequate supervision and control of children to 
inculcate good value systems in them.

The need for education and public enlightenment of parents, students and general public cannot be overemphasized. Education about the dangers or drug abuse should be provided by parents, teachers, traditional rulers, religious leaders and the mass media.

\subsubsection{Sexual Promiscuity}

Sexual promiscuity among students of educational institutions in Nigeria is another serious vice that calls for serious concern. Most of the students who for the first time gain some social freedom from their parents watchful eyes and guidance easily fall prey to the temptation of tasting the forbidden fruit. Some of them become so wild on the illicit lovemaking that they give most of their time and attention to it to the detriment of their studies. They become so much engaged in nocturnal activities that they sleep throughout the daytime in hostels or during lectures. Some other ones completely abandon their lectures to keep appointment with boyfriends or "sugar daddies"

Sexual promiscuity could lead to unwanted pregnancy babies or even pre-mature death. In an attempt to get rid of an unwanted pregnancy, complications may result which may lead to hospitalization and absence from lectures for those who may survive.

Some of the students are so morally bankrupt that they rely absolutely on their womanhood to "pass" their examination. They seduce fellow male students or examiners to assist them write their examination or award them pass marks as the case may be.

\subsubsection{Indecent/Obscene Dressing}

Educational institutions of learning in Nigeria have been bedeviled with indecent dressing particularly by female students. Most girls go bare, display their navels and boobs and wearing whatever to display size and shape of their private parts. It appears now that to be fashionable, one has to become half nude, dressed in sleeveless/see-through tops without bra. According to Irtwange(2004), this constitutes Weapons of Mass Distraction (WMD) and sexual harassment. This seductive dressing has profound negative effect on both the students and the lecturers alike as they can hardly concentrate in their academic work under such an environment.

Causes of immoral dressing range from failure of the family to instill strict moral values on their children from tender ages; peer group pressure cajoling upright students to go astray, to watching too many movies that portray American and European culture as superior and the in-thing.

There must be a moderate position that allows the students to dress in a certain way that would meet societal value. The higher institutions of learning have been fighting against other social vices such as cultism, examination malpractice and drug abuse but the issue of obscene dressing is only recently receiving attention.

Some professions have dress codes e.g Law and Medical students; Accountancy, Hospitality Management, etc which other professions can follow suit. Gladly, a general dress code has been introduced in each higher institutions of learning. I must quickly advise that such dress codes should make provision for lecturers to insist that their students must be decently dressed or be sent out of class. Parents and religious organizations also have a big role to play in curbing this menace through appropriate upbringing and counseling by guiding our young girls against indecent dressing to minimize the temptation of randy and sometimes insane men to rape them.

\subsubsection{Promoting Moral Values through Laws, Policies and Regulations}

According to the Constitution of the Federal Republic of Nigeria, (1999); dignity of labour, discipline, integrity, religious tolerance, and self-reliance amongst others are attributes that are considered as values in the national ethics or character. The National Policy on Education (NPE), (2004) also specified values system acceptable in the country and should therefore be inculcated in the learners through the quality of educational instructions. These include moral/spiritual values, dignity of human person, self-reliance and communal responsibility, amongst other; It particularly tasks tertiary institutions to "develop and inculcate proper values" implying that there are improper or negative values that should be nipped in the bud.

In our Tertiary Educational Institutions graduates are awarded certificates on the basis of character and learning. However, many wondered if the character aspect of assessing a candidate before conferring a Degree or any Certificate by educational institutions on such a candidate is still being considered as a serious factor. Why, because our value system has been seriously eroded and infected with gross immorality thereby rendering our students unworthy in 
character for awards of Degree/Certificate. These comments are premised on the low moral values of graduates in workplace, the incidents of cult violence, examination malpractice etc. that have come to become pronounced aspect of the public view of the contemporary tertiary institutions.

The Students Information Handbooks in our Tertiary Education System, e.g. Nasarawa State University, Keffi; Nasarawa State Polytechnic, Lafia have adequate provisions for conduct and discipline of students. If these rules and regulations guiding conduct of students are enforced by the school authorities, these wicked and immoral acts in our campuses would be reduced to the barest level.

\section{Conclusion}

In conclusion, the rate of increase in antisocial behaviours in our educational institutions is alarming. This negative trend in the social vices among students of higher institutions in Nigeria might be responsible for the general decline in the quality of the graduates being turned out by these institutions.

Therefore I strongly recommend that the responsibility of preventing or curbing general students vices in our tertiary institutions should be a collective one resting on parents, teachers, religious leaders, authorities of the institutions as well as government. Furthermore, I advocate that the African method of raising children should be returned to. For it takes one parent to give birth to a child, but it takes a village or community to raise the child.

Hence programmes should be put in place for socialization of children to return to family values. This can be achieved by empowering traditional institutions and community leaders to set up necessary machineries to resuscitate our much cherished moral values. The long term benefits of this is that our children would no longer be available as cultists, suicide bombers etc.

\section{References}

Amaele, M. A. (1990); Foundation of Education. African FEP Publishers limited Onistha, Nigeria.

Amao-kehinde, A. O. (2003). Cult activities and campus violence, Implication for psychological counseling" Education Today, 10 (2) 3643.

Anzene J. S. (2013). Trends in Examination Malpractice in Nigerian Educational System and its effects in the Socio-Economic and Political Development of Nigeria. Being a paper delivered at a one-day sensitization programme on the effects of Examination Malpractice organized by National Orientation Agency; 23/10/ 2013

Bell, D.D. (1970). Drug Addiction. "Bulletin on narcotics 22(2): 21-32

Bolarin, T. A. (2005). Values disorientation in the Nigerian System. In Ivowi, U. M. O (Ed) .Education for value. Lagos. The CIBN Press limited

Denga, D. I. (1991). Nigerian Education: Proposals for a smooth voyage to the year 2000 and beyond. London Rapid Education publisher

Enu, D. B; and Esu, A. E. O. (2011). Re-enginering Values Education in Nigeria schools as catalyst for National Development. International Education Studies 4(1), 147-153

Esu, A. E. O. (2009). Education for Humanistic values. In Ivowi, U. M. O (Ed). Education for value. Lagos. The CIBN Press limited

Ezeanya, Monsiguer (1979). "Indiscipline in schools" Nigerian Tide

Fadipe, J. O; and Oluchukwu E. E. (1999). Education Planning and Administration in Nigeria in the 21st century. A publication of the National Institute of Educational Planning and Administration (NEPA), Nigeria.

Igbokwe, J. M. (1997). "Drug abuse in a depressed economy". A lecture presented during the Physician week held at Abakaliki. Nigeria October 24

Irtwange, S. V. (2004). "Learning, character and University of Agriculture, Makurdi Degree." An Internal Memo, Students Affairs Department, University of Agriculture, Makurdi, Nigeria.

Kalusi, (2000). Education as a fundamental human right, the case of Nigeria In Kosemani, J. M (Ed). Nigeria, Education matters arising Vol I. Port Harcourt. Abe Publishers corporation.

Kayode, A. and Adeyinka, A. (2009). Pursuing Discipline and Ethical issues in Tertiary Institutions in Nigeria. African Research Review. An international multi-disciplinary journal, Vol 3(1), 284-300.

Ministry of Education. Benue state, (2001). "How to excel in examination and be free from cults" Makurdi Nigeria: Ministry of Education Publication.

National Orientation Agency, (2009). A survey of Nigeria Core values; Ibadan, Safari Books limited.

National Policy on Education, (2004): Federal Republic of Nigeria, Lagos. NERDC Press.

New Age Newspaper (2003). "The political relevance of cultism." Beyond Frontiers, 2003/2004, Edition 45-46.

Nwabueze, B. O. (1995). Crisis and problems in Education in Nigeria Ibadan spectrum books.

Nwadiani, M. (2005). "Curbing examination malpractice in the Nigerian educational system. A leader paper presented at the 1 st annual conference of the Faculty of Education, Ambrose Alli university, Ekpoma, November, 10/2012 
Olatunde, A. (1979). Self-medication: benefits precautions and dangers. London. Macmillan press Itd Orukpe, T. (1998). "Secret cults and the law". National Concord Newspaper, Thursday, December 17, Lagos Nigeria

Schaefer, R. L. (2000). Sociology. A brief Introduction. USA; McGraw-Hill company Inc. University Graduates in Nigeria. "A world bank/Nigerian institute of social and Economic Research Document". 